\title{
Survei Kemampuan Kondisi Fisik Peserta Kegiatan Ekstrakurikuler Bolavoli Sekolah Menengah Pertama
}

\author{
Siti Nurrochmah, M. Arif Setiawan* \\ Universitas Negeri Malang, Jl. Semarang No. 5 Malang, Jawa Timur, Indonesia \\ *Penulis korespondensi, Surel: setiawanmarif61@gmail.com
}

Paper received: 17-6-2021; revised: 1-7-2021; accepted: 8-7-2021

\begin{abstract}
The purpose of this study was to study and obtain information on the ability of arm muscle strength, agility of motion, and the explosive power of leg muscles and arm muscles of the extracurricular activities of volleyball teams of Junior High School 21 Malang City. This study uses a quantitative descriptive method with the subject of the study, namely the volleyball team extracurricular activity participants in Junior High School 21 Malang City, totaling 30 students consisting of 15 boys and 15 girls. The research instrument used in the form of test and non-test instruments, while the data collection using the form of test measurement techniques. Data analysis uses descriptive statistical techniques. The results of the analysis show that: 1) the physical condition component of the arm muscle strength component as a whole is at the moderate criteria of 50 percent, 2) the physical condition component of the agility of the motion element as a whole is in the medium criteria of 43.3 percent, 3) the physical condition component of the leg muscle explosive power component overall is in the medium criteria of 46.8 percent and the physical condition component of the arm muscle explosive power component overall is at the criteria of less than 36.8 percent. Based on the results of the study it can be concluded that the elements of arm muscle strength, agility of motion, leg muscle explosive power in the overall dominant are in the medium category, and the explosive power of the dominant arm muscle are in the less category.
\end{abstract}

Keywords: physical conditions; extracurricular; volleyball

\begin{abstract}
Abstrak
Tujuan penelitian ini adalah untuk mengkaji dan memperoleh informasi kemampuan kekuatan otot lengan, kelincahan gerak, dan daya ledak otot tungkai dan otot lengan peserta kegiatan ekstrakurikuler tim bolavoli SMP Negeri 21 Kota Malang. Penelitian ini menggunakan metode deskriptif kuantitatif dengan subjek penelitian yaitu peserta kegiatan ekstrakurikuler tim bolavoli di SMP Negeri 21 Kota Malang yang berjumlah 30 siswa yang terdiri dari 15 putra dan 15 putri. Instrumen penelitian yang digunakan berupa instrumen tes dan non tes, sedangkan pengumpulan data menggunakan teknik pengukuran bentuk tes. Analisis data menggunakan teknik statistika deskriptif. Hasil analisis menunjukkan bahwa: 1) pada komponen kondisi fisik unsur kekuatan otot lengan pada keseluruhan berada pada kriteria sedang 50 persen, 2) pada komponen kondisi fisik unsur kelincahan gerak pada keseluruhan berada pada kriteria sedang 43,3 persen, 3) pada komponen kondisi fisik unsur daya ledak otot tungkai pada keseluruhan berada pada kriteria sedang 46,8 persen dan pada komponen kondisi fisik unsur daya ledak otot lengan keseluruhan berada pada kriteria kurang 36,8 persen. Berdasarkan hasil penelitian dapat disimpulkan bahwa unsur kekuatan otot lengan, kelincahan gerak, daya ledak otot tungkai pada keseluruhan dominan berada pada kategori sedang, dan daya ledak otot lengan dominan berada pada kategori kurang.
\end{abstract}

Kata kunci: kondisi fisik; ekstrakurikuler; bolavoli

\section{Pendahuluan}

Pendidikan jasmani diajarkan beberapa materi yang meliputi beberapa aktivitas jasmani seperti olahraga aerobic dan olahraga anaerobic. salah satu olahraga anaerobic adalah permainan bolavoli. Permainan bolavoli biasanya juga termasuk dalam kegiatan 
ekstrakurikuler di beberapa sekolah yang ada. Olahraga pada dasarnya mempunyai pengertian dan hakikat yang sama, yaitu bahwa olahraga mengandung unsur gerak sebagai prinsip dasar dan bertujuan untuk mengolah manusia seutuhnya dan olahraga bukan hanya mengenai pengetahuan, keterampilan dan teknik, tetapi juga sikap mental seseorang (Sudarsini, 2013).

Ekstrakurikuler adalah kegiatan yang berada diluar jam pelajaran. Ekstrakurikuler itu memang sudah ada di sekolah meliputi: futsal, sepakbola, bolavoli, bola basket dll. Permainan bola voli sudah menjadi bagian kehidupan sehari-hari bagi masyarakat. Kegiatan ekstrakurikuler adalah tempat atau wahana untuk dapat mengembangkan bakat dan minat peserta didik, dimana peserta didik dapat memilih sendiri peminatan sesuai dengan kemampuan dan bakat yang dimilikinya (Lestari, 2016).

Permainan bola voli menggunakan sistem poin, salah satu tim dapat dinyatakan menang dalam permainan bola voli apabila sudah mencapai poin 25 terlebih dahulu dari salah satu tim dan kemengan tersebut diperoleh sebanyak 3 kali. Dilihat dari banyaknya poin yang harus didapat dalam permainan bola voli maka agar dapat bermain bola voli dengan baik dibutuhkan kondisi fisik yang baik. Kondisi fisik seorang atlet memegang peranan yang sangat penting dalam program latihannya. Kondisi fisik adalah satu dari komponen-komponen yang tidak dapat dipisahkan, baik peningkatannya, maupun pemeliharaannya. Jadi sebelum diterjunkan ke dalam gelanggang pertandingan, seorang atlet harus sudah berada dalam suatu kondisi fisik dan tingkatan fitness yang baik untuk menghadapinya intensitas kerja dan segala macam stress yang bakal dihadapinya dalam pertandingan.

Dalam menghadapi kejuaraan-kejuaraan tersebut, jika evennya antar pelajar SMP, SMP 21 Kota Malang selalu menonjolkan tim bolavoli untuk terlibat dalam pertandinganpertandingan tersebut. Terkait dengan frekuensi keikutsertaan tim bolavoli SMP 21 Kota Malang dalam berbagai kejuaraan tersebut, maka penting dilakukan pengukuran terhadap kondisi fisik tim bola voli di SMP 21 Kota Malang. Adapun kondisi fisik yang perlu dilakukan pengukuran bentuk tes adalah komponen-komponen kekuatan otot, kelincahan gerak dan daya ledak otot tungkai dan otot lengan. Sedangkan dalam penelitian ini pengukuran kondisi fisik terbatas hanya dilakukan pada peserta kegiatan ekstrakurikuler bolavoli SMP Negeri 21 Kota Malang. Dari hasil wawancara dengan pelatih bolavoli dari beberapa pertanyaan yang peneliti tanyakan secara keseluruhan pelatih selama ini tidak pernah melakukan pengukuran terhadap komponen kondisi fisik, disebabkan karena latihan lebih banyak pada peningkatan keterampilan dan teknik-teknik strategi bermain. Agar permainan bolavoli berjalan dengan baik maka terlebih dahulu setiap pemain harus menguasai beberapa keterampilan teknik dasar. Untuk siswa di sekolah menengah karena tarafnya/jenjangnya termasuk level awal maka disarankan terlebih dahulu menguasai keterampilan teknik dasar, seperti passing bawah, passing atas, service, smash dan block.

Kondisi fisik adalah suatu komponen yang tidak dapat dipisahkan begitu saja, baik peningkatan maupun pemeliharaan. Kondisi fisik sama dengan kemampuan biomotor atau kemampuan kondisi fisik. Hal ini diperkuat dalam penelitian yang dilakukan oleh Bella (2015) tentang "Kondisi Fisik Pemain Bolavoli Anak Usia 9-11 Tahun di Klub Bolavoli Putri Wahana Utama Purwodadi Tahun 2013" menyatakan bahwa, kondisi fisik anak rata-rata dalam kriteria sedang dan keterampilan teknik dasar dalam kategori kurang. Sama halnya penelitian yang dilakukan oleh Sovensi, dkk (2019) tentang "Kondisi Fisik Pemain Bolavoli Club di Kota Lubuklinggau" menyatakan bahwa daya ledak otot tungkai berada pada kategori baik. Daya 
tahan pemain bolavoli club caroline di kategori cukup. Kecepatan pemain bolavoli club caroline dikategori baik. Kelincahan pemain club JVC di kategori baik. Kekuatan otot perut pemain bolavoli club caroline dan club JVC di kategori baik. Hal ini berdasarkan data yang telah dipaparkan sebagai berikut. Hasil tes daya tahan yang dimiliki oleh pemain bolavoli club caroline di kategori sedang dan pemain bolavoli club JVC di kategori baik.

Maulidin (2017) kekuatan merupakan suatu gerakan atau gaya yang dihasilkan oleh otot atau sekelompok otot dalam suatu kontraksi maksimal sehingga terjadi perubahan pada tahanan atau beban. Beban tersebut bisa didapat dari beban badan sendiri atau dari luar. Kekuatan dapat ditingkatkan dengan latihan yang menimbulkan tahanan, misalnya, mendorong, menarik dan mengangkat. Hal ini diperkuat dalam penelitian yang pernah dilakukan oleh Ma \& Syafei (2019) tentang "Hubungan Kekuatan Otot Lengan, Koordinasi Mata Tangan, dan Rasa Percaya Diri dengan Keterampilan Smash pada Ekstrakurikuler Permainan Bolavoli di SMPN 3 Tirtajaya Karawang" berdasarkan hasil yang diperoleh, menunjukkan bahwa terdapat hubungan yang positif secara bersama-sama antara kekuatan otot lengan $\left(\mathrm{X}_{1}\right)$ koordinasi mata tangan $\left(\mathrm{X}_{2}\right)$ dan rasa percaya diri $\left(\mathrm{X}_{3}\right)$ secara bersama-sama terhadap hasil keterampilan smash bolavoli (Y).

Kelincahan (agility) adalah kemampuan seseorang untuk dapat mengubah arah dengan cepat dan tepat pada waktu bergerak tanpa kehilangan keseimbangan (Sumaryoto \& Nopembri, 2017). Kelincahan tentu memiliki keterkaitan dengan kelentukan tanpa adanya kelentukan yang baik maka seseorang tidak dapat bergerak dengan lincah nantinya. Hal ini yang pernah dilakukan oleh Sya'bani \& Nurrochmah (2019) yang meneliti tentang latihan kelincahan $S$-Run dan Z-Run terhadap peningkatan kemampuan kelincahan peserta putra ekstrakurikuler bolavoli dan hasilnya latihan S-Run dan Z-Run Dapat meningkatkan kemampuan komponen kelincahan.

Amiq (2016) menyatakan bahwa daya ledak (muscular power) adalah kemampuan kekuatan seseorang untuk mempergunakan kekuatan maksimum yang dikerahkan dalam waktu yang sependek-pendeknya. Daya ledak diperlukan pada kemampuan dalam bermain bolavoli, contohnya pada kemampuan servis. Menurut Hanafi, dkk. (2019) daya ledak merupakan suatu komponen kondisi fisik yang dapat menentukan hasil prestasi seseorang dalam keterampilan gerak. Berdasarkan masalah di atas, peneliti merasa tertarik untuk melakukan penelitian tentang komponen kondisi fisik yang berjudul. Survei Kemampuan Kondisi Fisik Peserta Kegiatan Ekstrakurikuler Tim Bolavoli SMP Negeri 21 Kota Malang. Hal ini diperkuat dalam penelitian yang dilakukan Nurrochmah (2015) efektifitas pelatihan beban dinamis dan statis untuk meningkatkan kekuatan dan daya eksplosif otot tungkai dan lengan. Berdasarkan hasil penelitian 1) pelatih diagonal step lebih efektif meningkat variabel kekuatan otot tungkai dan lengan. 2) pelatih lateral hop lebih efektif meningkat variabel daya eksplosif otot tungkai dan lengan. 3) pelatih leg press cepat efektif meningkatkan variabel daya eksplosif otot tungkai dan kekuatan otot tungkai dan 4) leg press lambat meningkatkan kekuatan otot tungkai, namun otot lengan mengalami penurunan. Sama halnya penelitian yang dilakukan oleh Gunawan, dkk. (2016) tentang "Pelatihan Meloncati Rintangan Setinggi 50cm Ke Kiri Ke Kanan 10 Repetisi 3 Set Meningkatkan Daya Ledak Otot Tungkai Siswa Putra Peserta Ekstrakurikuler Bolavoli Smp Negeri 2 Mengwi Tahun Pelajaran 2015/2016" berdasarkan hasil penelitian maka dapat disimpulkan bahwa pelatihan meloncati rintangan setinggi $50 \mathrm{~cm}$ 10 repetisi 3 set dengan 5 repetisi 6 set terhadap daya ledak otot tungkai pada siswa putra peserta ekstrakurikuler SMP Negeri 2 mengwi tahun pelajaran 2015/2016 sama-sama 
menyatakan hipotesis nol ditolak. Hasil $t$ hitung kedua kelompok tidak ada perbedaan yang signifikan dan hipotesis nol diterima, sehingga didapatkan hasil bahwa pelatihan yang berpengaruh lebih baik.

\section{Metode}

Penelitian ini menggunakan rancangan penelitian survei. Dilihat dari tujuan penelitian, penelitian ini termasuk penelitian deskriptif kuantitatif. Pada penelitian ini subjek yang diteliti yaitu peserta kegiatan ekstrakurikuler tim bola voli SMP Negeri 21 Malang yang berjumlah 30 peserta yang terdiri dari 15 putra dan 15 putri. Teknik pengumpulan data yang digunakan pada penelitian ini merupakan pengukuran bentuk tes dan pengukuran. Bentuk tes yang diberikan yaitu berupa tes kekuatan, kelincahan, dan daya ledak pada peserta ekstrakurikuler tim bola voli SMP Negeri 21 Malang. Macam-macam tes yang digunakan dalam tes kekuatan otot lengan (handgrip dynamometer), kelincahan gerak (T-test), daya ledak otot tungkai (Vertical Jump ), dan daya ledak otot lengan (Bola Medicine).

\section{Hasil dan Pembahasan}

\subsection{Hasil}

Tabel 1. Penyajian Hasil Analisis Data Hasil Tes Kemampuan Kondisi Fisik Untuk Olahraga Permainan Bolavoli Pada Peserta Kegiatan Ekstrakurikuler Bolavoli di SMP Negeri 21 Kota Malang Kelompok Putra

\begin{tabular}{|c|c|c|c|c|c|}
\hline \multirow[t]{2}{*}{ No. } & \multirow[t]{2}{*}{ Jenis Tes } & \multicolumn{4}{|c|}{ Ukuran Statistik } \\
\hline & & Mean & SD.S & Varian.S & KV (\%) \\
\hline 1. & $\begin{array}{l}\text { Kekuatan otot lengan } \\
\text { (handgrip dynamometer) }\end{array}$ & $21,74 \mathrm{~kg}$ & $2,0170 \mathrm{~kg}$ & $3,787 \mathrm{~kg}$ & 9,27 \\
\hline 2. & Tes lari $T$ - Test & 13,04 detik & 1,1933 detik & 1,329 detik & 9,15 \\
\hline 3. & Vertical Jump & $262 \mathrm{~cm}$ & $14,5022 \mathrm{~cm}$ & $196 \mathrm{~cm}$ & 5,53 \\
\hline 4. & $\begin{array}{l}\text { Lempar Bola Medicine } \\
\text { tanpa awalan }\end{array}$ & 3,90 meter & 0,3820 meter & 0,136 meter & 9,79 \\
\hline
\end{tabular}

$\begin{array}{ll}\text { Keterangan: } & \\ \text { Mean } & =\text { Nilai Tengah } \\ \text { SD.S } & =\text { Standar Deviasi Sampel } \\ \text { Varian.S } & =\text { Variansi Sampel } \\ \text { KV } & =\text { Koefisien Variansi }\end{array}$

Berdasarkan sajian pada tabel 1, hasil analisis data pada tes handgrip dynamometer, $t$ test, vertical jump dan bola medicine untuk peserta kegiatan ekstrakurikuler tim bolavoli SMP Negeri 21 Kota Malang kelompok putra berjumlah 15 peserta maka diperoleh hasil tes handgrip dynamometer skor mean 21,74 kg, skor SD 2,0170 kg, varian diperoleh 4,0683 kg, KV $9,27 \%$. Tes $t$ - test memperoleh skor mean 13,04 detik, skor SD 1,1933 detik, varian diperoleh 1,4242 detik, KV 9,15 \%. Tes vertical jump memperoleh skor mean $262 \mathrm{~cm}$, skor SD 14,5022 $\mathrm{cm}$, varian diperoleh $210,31 \mathrm{~cm}, \mathrm{KV} 5,53 \%$. Tes bola medicine memperoleh skor mean 3,90 meter, skor SD 0,3820 meter, varian diperoleh 0,146 meter, dan KV 9,79\%. 
Tabel 2. Penyajian Hasil Analisis Data Hasil Tes Kemampuan Kondisi Fisik Untuk Olahraga Permainan Bolavoli Pada Peserta Kegiatan Ekstrakurikuler Bolavoli di SMP Negeri 21 Kota Malang Kelompok Putri

\begin{tabular}{|c|c|c|c|c|c|}
\hline \multirow[t]{2}{*}{ No. } & \multirow[t]{2}{*}{ Jenis Tes } & \multicolumn{4}{|c|}{ Ukuran Statistik } \\
\hline & & Mean & SD.S & Varian.S & KV (\%) \\
\hline 1. & $\begin{array}{l}\text { Kekuatan otot lengan } \\
\text { (handgrip } \\
\text { dynamometer) }\end{array}$ & $21,99 \mathrm{~kg}$ & $0,2753 \mathrm{~kg}$ & $7,080 \mathrm{~kg}$ & 1,25 \\
\hline 2. & Tes lari $T$ - Test & 12,17 detik & 1,0265 detik & 0,984 detik & 8,44 \\
\hline 3. & Vertical Jump & $259 \mathrm{~cm}$ & $10,7238 \mathrm{~cm}$ & $107 \mathrm{~cm}$ & 4,14 \\
\hline 4. & $\begin{array}{l}\text { Lemar Bola Medicine } \\
\text { tanpa awalan }\end{array}$ & 3,77 meter & $\begin{array}{l}0,4568 \\
\text { meter }\end{array}$ & 0,195 meter & 12,14 \\
\hline
\end{tabular}

$\begin{array}{ll}\text { Keterangan: } & \\ \text { Mean } & =\text { Nilai Tengah } \\ \text { SD.S } & =\text { Standar Deviasi Sampel } \\ \text { Varian.S } & =\text { Variansi Sampel } \\ \text { KV } & =\text { Koefisien Variansi }\end{array}$

Berdasarkan sajian pada tabel 2, hasil analisis data pada tes handgrip dynamometer, $t$ test, tes vertical jump dan bola medicine untuk peserta kegiatan ekstrakurikuler tim bolavoli SMP Negeri 21 Kota Malang kelompok putri yang berjumlah 15 peserta maka diperoleh hasil tes handgrip dynamometer skor mean 21,99 kg, skor SD 0,2753 kg, varian diperoleh 0,075 kg, KV 1,25 \%. Tes $t$ - test memperoleh skor mean 12,17 detik, skor SD 1,0265 detik, varian diperoleh 1,0538 detik, KV 8,44 \%. Tes vertical jump memperoleh skor mean $259 \mathrm{~cm}$, skor SD $10,7238 \mathrm{~cm}$, varian $115 \mathrm{~cm}, \mathrm{KV}$ 4,14 \%. Tes bola medicine memperoleh skor mean 3,77 meter, skor SD 0,4568 meter, varian diperoleh 0,2087 meter, KV 12,14\%.

Tabel 3. Penyajian Hasil Analisis Data Hasil Tes Kemampuan Kondisi Fisik Untuk Olahraga Permainan Bolavoli Pada Peserta Kegiatan Ekstrakurikuler Bolavoli di SMP Negeri 21 Kota Malang Kelompok Putra dan Putri

\begin{tabular}{|c|c|c|c|c|c|}
\hline \multirow{2}{*}{ No. } & \multirow{2}{*}{ Jenis Tes } & \multicolumn{4}{|c|}{ Ukuran Statistik } \\
\hline & & Mean & SD.S & Varian.S & KV (\%) \\
\hline 1. & $\begin{array}{l}\text { Kekuatan otot lengan } \\
\text { (handgrip dynamometer) }\end{array}$ & $21,87 \mathrm{~kg}$ & $2,3750 \mathrm{~kg}$ & $5,453 \mathrm{~kg}$ & 10,89 \\
\hline 2. & Tes lari $T$-Test & 12,60 detik & 1,1807 detik & 1,348 detik & 9,37 \\
\hline 3. & Vertical Jump & $261,23 \mathrm{~cm}$ & $12,4365 \mathrm{~cm}$ & $148 \mathrm{~cm}$ & 5,75 \\
\hline 4. & $\begin{array}{l}\text { Lempar Bola Medicine } \\
\text { tanpa awalan }\end{array}$ & 3,83 meter & 0,4282 meter & 0,170 meter & 11,18 \\
\hline
\end{tabular}

Keterangan:

\begin{tabular}{|c|c|}
\hline Mean & = Nilai Tengah \\
\hline SD.S & $=$ Standar Deviasi Sampel \\
\hline Varian.S & = Variansi Sampel \\
\hline KV & = Koefisien Variansi \\
\hline
\end{tabular}

Berdasarkan sajian pada tabel 3, hasil analisis data pada tes handgrip dynamometer, bola medicine, $t$ - test, dan tes vertical jump untuk peserta kegiatan ekstrakurikuler tim bolavoli SMP Negeri 21 Kota Malang kelompok putra dan putri yang berjumlah 30 peserta maka diperoleh hasil tes handgrip dynamometer skor mean 21,87 kg, skor SD 2,3750 kg, varian diperoleh 
5,6409 kg, dan KV 10,89 \%. Tes t- test memperoleh skor mean 12,60 detik, skor SD 1,1807 meter, varian 1,3941 detik, KV 9,37 \% . Tes vertical jump memperoleh skor mean $261 \mathrm{~cm}$, skor SD 12,4365 cm, varian diperoleh 154,66 cm, KV 5,75 \%. Tes bola medicine memperoleh skor mean 3,83 meter, skor SD 0,4282 meter, varian diperoleh 0,1834 meter, KV 11,18\%.

\subsection{Pembahasan}

Sesuai dengan rumusan masalah yaitu bagaimana kemampuan kondisi fisik komponen kekuatan otot lengan, kelincahan gerak, dan daya ledak (otot tungkai), dan daya ledak (otot lengan) pada peserta kegiatan ekstrakurikuler bolavoli SMP Negeri 21 Kota Malang, maka untuk memecahkan masalah tersebut peneliti telah melakukan analisis data menggunakan teknik statistika deskriptif yang meliputi statistik bentuk tendensi sentral dan variabilitas untuk menganalisis data hasil tes handgrip dynamometer, lari t- test, loncat tegak vertical jump, dan lempar bola medicine tanpa awalan. Data yang telah diperoleh selanjutnya dianalisis sesuai teknik yang ditetapkan, sehingga hasil analisis yang telah diperoleh dan disajikan pada halaman terdahulu yaitu sub bab deskripsi data dan analisis data. Berdasarkan hasil analisis data, berikut akan disajikan pembahasan hasil penelitian yang merujuk pada rumusan masalah dan analisis data dari peserta kegiatan ekstrakurikuler bolavoli SMP Negeri 21 Kota Malang. Berdasarkan latar belakang masalah yang diteliti pada bab I, maka pada sajian ini yang dibahas meliputi hasil penelitian dari masing-masing komponen kondisi fisik yang meliputi (a) pembahasan hasil penelitian kemampuan kondisi fisik komponen kekuatan otot lengan peserta kegiatan ekstrakurikuler bolavoli SMP Negeri 21 Kota Malang. (b) pembahasan hasil penelitian kemampuan kondisi fisik komponen kelincahan gerak peserta kegiatan ekstrakurikuler bolavoli SMP Negeri 21 Kota Malang dan (c) pembahasan hasil penelitian kemampuan daya ledak otot tungkai dan otot lengan peserta kegiatan ekstrakurikuler bolavoli SMP Negeri 21 Kota Malang. Berikut dipaparkan pembahasan hasil penelitian dari hasil komponen tersebut.

\subsubsection{Pembahasan Hasil Analisis Data Komponen Kekuatan Otot Lengan Peserta Kegiatan Ekstrakurikuler Tim Bolavoli SMP Negeri 21 Kota Malang}

Secara keseluruhan dari hasil analisis komponen kekuatan otot lengan berupa tes handgrip dynamometer kg pada kelompok putra yang termasuk kriteria baik sampai baik sekali yaitu terdapat 2 orang $(13,2 \%)$ dari 15 orang, sedangkan yang berada di bawah kriteria sedang sampai kurang sekali berjumlah 13 orang (86,8\%) dari 15 orang. Pada kelompok putri yang termasuk pada kriteria baik sampai baik sekali yaitu berjumlah 6 orang $(39,9 \%)$ dari 15 orang, sedangkan yang berada di bawah sedang sampai kurang sekali berjumlah 9 orang $(60,1 \%)$ dari 15 orang. Berarti pada tim putra dan tim putri komponen kondisi fisik kekuatan otot lengan dominan berada pada kriteria di bawah baik atau kriteria sedang sampai kurang sekali. Norma kriteria tes dibuat berdasarkan data dari hasil tes pada tim bolavoli SMP Negeri 21 Kota Malang. Sebenarnya sebagai tim bolavoli yang ikut bertanding norma tes berada pada kriteria minimal sedang atau kriteria baik.

Kekuatan otot lengan berada di bawah kriteria baik sebagai tim yang ikut kompetisi semestinya berada pada kriteria baik minimal sedang. Hal ini disebabkan karena latihan dilakukan seminggu 2 kali pertemuan, latihan tidak banyak difokuskan pada kondisi fisik umumnya unsur-unsur kondisi fisik seperti kekuatan otot lengan, kelincahan gerak dan daya ledak otot tungkai. Di samping itu pula di dalam latihan kurang menerapkan prinsip-prinsip 
latihan yang berhubungan dengan unsur kondisi fisik yaitu misalnya prinsip latihan beban berlebih. Purnama, dkk. (2017) menyatakan bahwa overload adalah tingkat kebugaran tertentu diberikan beban latihan dengan tingkat intensitas yang ditetapkan. Prinsip yang lain seperti prinsip variasi latihan juga tidak banyak diterapkan. Hal ini diperkuat dalam penelitian yang dilakukan oleh Ghazali (2016) tentang "Kontribusi Kekuatan Otot Lengan Terhadap Kemampuan Servis Atas Atlet Bolavoli" kesimpulan hasil penelitian menghasilkan bahwa terdapat kontribusi yang signifikan antara kekuatan otot lengan terhadap servis atas atlet putra voli Mufakat Volly Club (MVC) Pekanbaru. Sama halnya dengan penelitian yang dilakukan oleh Nasution (2015) tentang "Hubungan Kekuatan Otot Lengan dan Percaya Diri Dengan Keterampilan Open Spike Pada Pembelajaran Permainan Bolavoli Atlet Pelatkab Bolavoli Putri Kabupaten Karawang" dalam penelitian ini hasil pengujian hipotesis pertama, terdapat hubungan positif antara percaya diri $\left(\mathrm{X}_{1}\right)$ dengan keterampilan open spike bolavoli $(\mathrm{Y})$. Kedua, terdapat hubungan positif antara koordinasi mata tangan $\left(\mathrm{X}_{2}\right)$ dengan keterampilan open spike bolavoli $(\mathrm{Y})$. Ketiga, terdapat hubungan positif antara percaya diri $\left(\mathrm{X}_{3}\right)$ dengan keterampilan open spike bolavoli (Y). Keempat, terdapat hubungan positif antara kekuatan otot lengan $\left(\mathrm{X}_{1}\right)$, koordinasi mata tangan $\left(\mathrm{X}_{2}\right)$, percaya diri $\left(\mathrm{X}_{3}\right)$ dengan keterampilan open spike bolavoli (Y). Dalam penelitian ini menyimpulkan bahwa kekuatan otot lengan, koordinasi mata tangan, dan percaya diri memiliki hubungan yang signifikan dengan keterampilan open spike bolavoli.

\subsubsection{Pembahasan Hasil Analisis Data Komponen Kelincahan Gerak Peserta Kegiatan Ekstrakurikuler Tim Bolavoli SMP Negeri 21 Kota Malang}

Secara keseluruhan dari paparan hasil analisis komponen bentuk kelincahan gerak berupa $t$ - test pada kelompok putra yang termasuk pada kriteria baik sampai baik sekali yaitu berjumlah 13 orang $(88,9 \%)$ dari 15 orang, sedangkan yang berada di bawah kriteria sedang sampai kurang sekali berjumlah 2 orang $(13,3 \%)$ dari 15 orang. Untuk kelompok putri yang termasuk pada kriteria baik sampai baik sekali yaitu berjumlah 7 orang (46,6\%) dari 15 orang, sedangkan yang berada di bawah kriteria sedang sampai kurang sekali berjumlah 8 orang $(53,4 \%)$ dari 15 orang.

Berarti komponen kelincahan gerak dari peserta kegiatan ekstrakurikuler bolavoli SMP Negeri 21 Kota Malang khusus tim putra cenderung berada pada norma kriteria di atas baik sampai baik sekali. Sedangkan komponen kelincahan gerak dari peserta kegiatan ekstrakurikuler bolavoli SMP Negeri 21 Kota Malang khusus tim putri cenderung berada pada norma kriteria di bawah sedang sampai kurang sekali. Norma kriteria tes dibuat berdasarkan data dari hasil tes pada tim peserta kegiatan ekstrakurikuler bolavoli SMP Negeri 21 Kota Malang. Sebaiknya sebagai tim yang sering ikut kompetisi seharusnya komponen kelincahan gerak berada pada norma kriteria baik, minimal sedang baik tim putra maupun tim putri. Hal ini disebabkan karena latihan dilakukan seminggu dua kali pertemuan, latihan tidak banyak difokuskan pada kondisi fisik umumnya unsur-unsur kondisi fisik seperti kelincahan gerak. Disamping itu pula prinsip-prinsip latihan yang berhubungan dengan unsur kondisi fisik yang dilatih, yaitu seperti prinsip variasi latihan juga tidak banyak diterapkan. Variasi latihan penting dilakukan untuk menghindari kebosanan dan memacu peserta aktif berlatih. Terkait dengan penerapan variasi latihan, Budiwanto (2012) menyatakan bahwa dalam upaya mengatasi kebosanan dalam latihan yang sangat monoton, diharapkan seorang pelatih berkreatif dengan memiliki banyak prinsip-prinsip pengetahuan dan berbagai jenis latihan yang memungkinkan dapat bervariasi dan berganti-ganti secara periodik, dan dalam latihan 
dapat diperkaya/diperkuat dengan mengadopsi pola gerakan teknik yang sama dengan cara yang berbeda, atau dapat mengembangkan kemampuan gerak yang diperlukan dengan olahraga. misalnya untuk pemain bolavoli, bolabasket, sepakbola atau pelari/pelompat tinggi yang berusaha memperbaiki power otot tungkai, atau untuk setiap olahraga yang memerlukan suatu kekuatan tungkai/power untuk melompat ke atas, kesamping kiri dan kanan sangat perlu ditekankan pada latihan melompat setiap hari latihan. Hal ini diperkuat oleh penelitian yang dilakukan oleh Sya'bani, Rifai \& Nurrochmah (2019) tentang "Pengaruh Latihan Kelincahan sRun dan z-Run Terhadap Peningkatan Kemampuan Kelincahan Peserta Putra Ekstrakurikuler Bolabasket" dalam penelitian ini menyimpulkan bahwa ada pengaruh pada latihan $s$-Run terhadap peningkatan kelincahan untuk peserta putra ekstrakurikuler bolabasket SMA Negeri 1 Lawang.

\subsubsection{Pembahasan Hasil Analisis Data Komponen Daya Ledak (Otot Tungkai dan Otot Lengan) Peserta Kegiatan Ekstrakurikuler Tim Bolavoli SMP Negeri 21 Kota Malang}

Secara keseluruhan dipaparkan hasil analisis komponen daya ledak otot tungkai dan otot lengan berupa tes vertical jump pada kelompok putra yang termasuk pada kriteria baik sampai baik sekali yaitu berjumlah 5 orang $(33,4 \%)$ dari 15 orang, sedangkan yang berada di bawah kriteria sedang sampai kurang sekali berjumlah 10 orang $(66,6 \%)$ dari 15 orang. Untuk kelompok putri yang termasuk pada kriteria baik sampai baik sekali yaitu berjumlah 4 orang $(26,7 \%)$ dari 15 orang, sedangkan yang berada di bawah kriteria sedang sampai kurang sekali berjumlah 11 orang $(73,3 \%)$ dari 15 orang. Sedangkan untuk hasil analisis daya ledak otot lengan berupa tes bola medicine meter pada kelompok putra yang termasuk pada kriteria baik sampai baik sekali yaitu berjumlah 4 orang $(26,6 \%)$ dari 15 orang, sedangkan yang berada di bawah kriteria sedang sampai kurang sekali berjumlah 11 orang $(73,4 \%)$ dari 15 orang. Untuk kelompok putri yang termasuk pada kriteria baik sampai baik sekali yaitu berjumlah 7 orang $(46,6 \%)$ dari 15 orang, sedangkan yang berada di bawah kriteria sedang sampai kurang sekali berjumlah 8 orang $(53,4 \%)$ dari 15 orang. Berarti pada tim putra dan tim putri komponen kondisi fisik daya ledak otot tungkai dan otot lengan peserta kegiatan ekstrakurikuler tim bolavoli SMP Negeri 21 Kota Malang dominan berada pada norma kriteria di bawah baik sampai baik sekali. Norma kriteria tes dibuat berdasarkan data dari hasil tes pada tim bolavoli SMP 21 Kota Malang. Sebaiknya sebagai tim bolavoli yang sering ikut bertanding norma tes berada di kriteria baik, minimal sedang. Hal ini disebabkan karena latihan dilakukan seminggu 2 kali pertemuan, latihan tidak banyak difokuskan pada kondisi fisik umumnya unsur-unsur kondisi fisik. Disamping itu pula di dalam latihan kurang menerapkan prinsip-prinsip latihan yang berhubungan dengan unsur kondisi fisik yang dilatih, misalnya prinsip individual atau individualisasi. Prinsip individualisasi merupakan salah satu syarat penting dalam latihan kontemporer, maka harus diterapkan kepada setiap atlet atau mereka mempunyai tingkat prestasi yang sama (Harsono, 2015). Dalam penelitian yang pernah dilakukan oleh Nurkholis (2012) tentang "Kontribusi Kemampuan Daya Ledak Otot Tungkai, Tinggi Badan dan Kekuatan Otot Lengan Terhadap Ketepatan Sasaran Pukulan Open Spike Olahraga Bolavoli" dalam penelitian ini hasil uji signifikan menunjukkan bahwa nilai F-hitung yang dihasilkan lebih dari pada F-. Dalam penelitian ini menyimpulkan bahwa ketiga variabel bebas terdapat daya ledak otot tungkai, tinggi badan dan kekuatan otot lengan secara bersamaan memiliki hubungan yang signifikan terhadap ketepatan sasaran pukulan Open Spike bolavoli. Sama halnya penelitian yang dilakukan oleh Yodi \& Mardela (2019) tentang "Daya Ledak Otot Tungkai dan 
Otot Lengan Berhubungan Terhadap Kemampuan Smash Bolavoli" dalam penelitian ini hasil penelitian daya ledak otot tungkai memberikan korelasi terhadap kemampuan smash bolavoli $\left(r_{\text {hitung }} 0,44>r_{\text {tabel }} 0,38\right)$. Daya ledak otot lengan memberikan korelasi terhadap kemampuan smash bolavoli $\left(r_{\text {hitung }} 0,58>r_{\text {tabel }} 0,38\right)$. Dalam penelitian ini menyimpulkan bahwa daya ledak otot tungkai dan daya ledak otot lengan memberikan korelasi secara bersama-sama terhadap kemampuan smash bolavoli $\left(r_{\text {hitung }} 0,62>r_{\text {tabel }} 0,38\right)$.

Dalam penelitian ini data yang diperoleh setelah disajikan melalui deskripsi data, selanjutnya data dianalisis dengan menggunakan teknik standar deviasi sampel, varian dan koefisien variansi. Berikut ini akan disajikan hasil analisis data.

Tabel 4. Koefisien Variasi Seluruh Butir Tes Kelompok Putra Peserta Kegiatan Ekstrakurikuler Bolavoli SMP Negeri 21 Kota Malang

\begin{tabular}{clcc}
\hline No & \multicolumn{1}{c}{ Unsur Kondisi Fisik } & Jenis Tes & KV (\%) \\
\hline 1. & Kekuatan & Handgrip Dynamometer & 9,27 \\
2. & Kelincahan & T- Test & 9,15 \\
3. & Daya Ledak (Otot Tungkai) & Vertical Jump & 5,53 \\
4. & Daya Ledak (Otot Lengan) & Bola Medicine & 9,79 \\
\hline
\end{tabular}

Berdasarkan koefisien variansi seluruh butir tes kelompok putra peserta kegiatan ekstrakurikuler bolavoli SMP Negeri 21 Kota Malang mendapatkan hasil tes daya ledak otot tungkai vertical jump menunjukkan lebih memusat dibandingkan butir tes lainnya, artinya tes vertical jump banyak peserta didik yang mempunyai skor mendekati baik sama antara individu. Sedangkan hasil tes daya ledak otot lengan bola medicine, koefisien variansi diperoleh $9,79 \%$, berarti butir tes daya ledak otot lengan bola medicine lebih menyebar atau beragam artinya pada tes tersebut antar individu memperoleh skor yang sangat bervariasi. Berikut keadaan koefisien variansi seluruh butir tes pada kelompok putra akan disajikan dalam bentuk grafik.

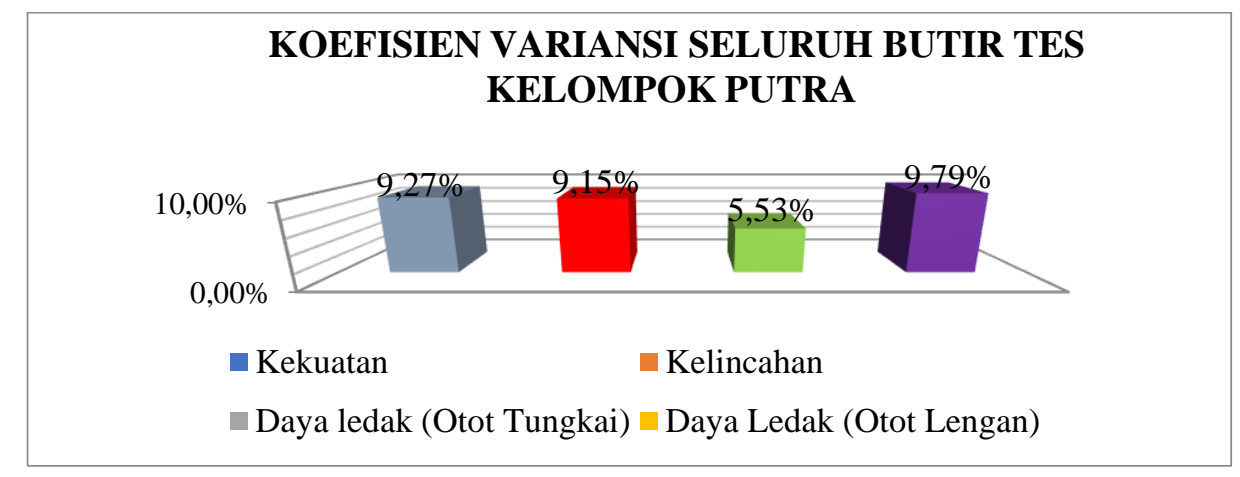

Gambar 1. Grafik Penyebaran Hasil Koefisien Variansi Pada Kelompok Putra Peserta Kegiatan Ekstrakurikuler Bolavoli SMP Negeri 21 Kota Malang 
Tabel 5. Koefisien Variansi Seluruh Butir Tes Kelompok Putri Peserta Kegiatan Ekstrakurikuler Bolavoli SMP Negeri 21 Kota Malang

\begin{tabular}{clcc}
\hline No & Unsur Kondisi Fisik & Jenis Tes & KV (\%) \\
\hline 1. & Kekuatan & Handgrip Dynamometer & 1,25 \\
2. & Kelincahan & T-Test & 8,44 \\
3. & Daya Ledak (Otot Tungkai) & Vertical Jump & 4,14 \\
4. & Daya Ledak (Otot Lengan) & Bola Medicine & 12,14 \\
\hline
\end{tabular}

Berdasarkan koefisien variansi seluruh butir tes kelompok putri peserta kegiatan ekstrakurikuler bolavoli SMP Negeri 21 Kota Malang mendapatkan hasil tes kekuatan otot handgrip dynamometer menunjukkan lebih memusat dibandingkan butir tes lainnya, artinya tes handgrip dynamometer banyak peserta didik yang mempunyai skor mendekati baik sama antar individu. Sedangkan hasil tes daya ledak otot lengan bola medicine, koefisien variansi diperoleh $12,14 \%$, berarti butir tes daya ledak otot lengan bola medicine lebih menyebar atau beragam artinya pada tes tersebut antar individu memperoleh skor yang sangat bervariasi. Berikut koefisien variansi seluruh butir tes pada kelompok putri akan disajikan dalam bentuk grafik.

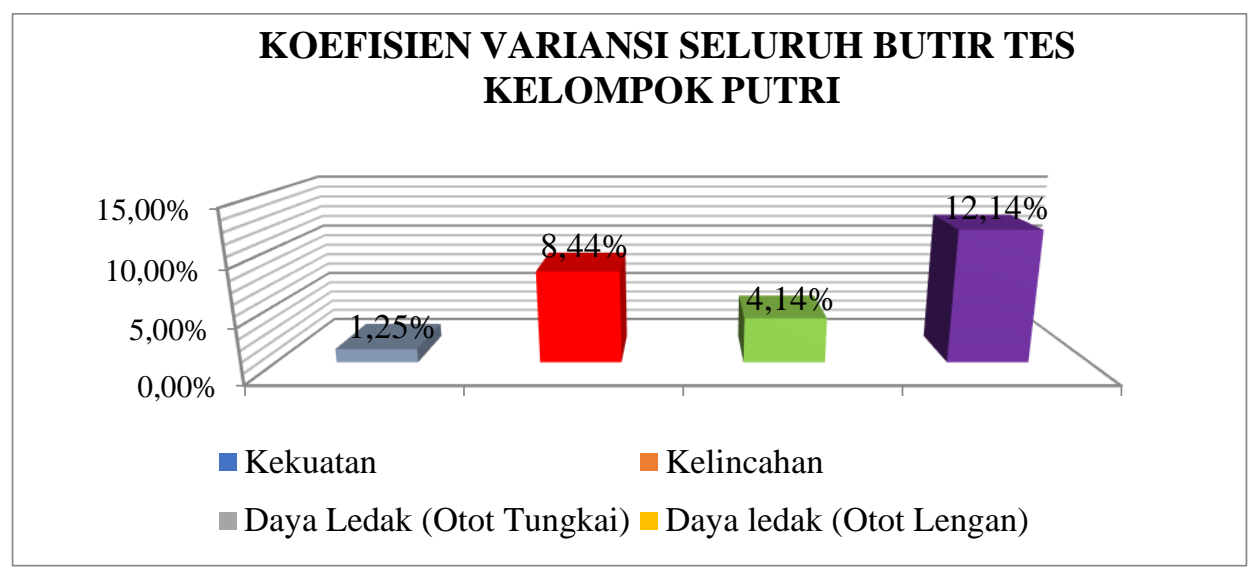

Gambar 2. Grafik Penyebaran Hasil Koefisien Variansi Pada Kelompok Putri Peserta Kegiatan Ekstrakurikuler Bolavoli SMP Negeri 21 Kota Malang

Tabel 6. Rangkuman Hasil Koefisien Variansi dari Peserta Kegiatan Ekstrakurikuler Bolavoli SMP Negeri 21 Kota Malang Kelompok Putra dan Putri

\begin{tabular}{cccc}
\hline Jenis Kelamin & Jenis Tes & KV (\%) & Keterangan \\
\hline Putri & Vertical Jump & 4,14 & \multirow{2}{*}{ Memusat } \\
Putra & Vertical Jump & 5,53 & \\
\hline Putra & Bola Medicine & 9,79 & \multirow{2}{*}{ Menyebar } \\
Putri & Bola Medicine & 12,14 & \\
\hline
\end{tabular}

Dengan demikian merujuk pada tabel 6 tentang rangkuman hasil koefisien variansi dari peserta kegiatan ekstrakurikuler bolavoli SMP Negeri 21 Kota Malang pada kelompok putra dan putri dapat dikemukakan bahwa diantara kedua kondisi fisik tersebut hasil tes Vertical Jump pada kelompok putri yaitu sebesar 4,14\% lebih memusat, sedangkan dari kedua kondisi fisik hasil tes bola medicine pada kelompok putri sebesar 12,14\% lebih menyebar. 


\section{Simpulan}

Berdasarkan hasil penelitian dapat disimpulkan bahwa unsur kekuatan otot lengan, kelincahan gerak, daya ledak otot tungkai pada keseluruhan dominan berada pada kategori sedang, dan daya ledak otot lengan dominan berada pada kategori kurang. Peneliti menyarankan bagi para peserta kegiatan ekstrakurikuler bolavoli SMP Negeri 21 Kota Malang lebih menerapkan prinsip-prinsip latihan, memberikan latihan yang berhubungan dengan unsur-unsur kekuatan, kelincahan, dan daya ledak (otot tungkai dan otot lengan), memberikan latihan beban, serta memperhatikan frekuensi, intensitas dan durasi latihan, hal ini bertujuan untuk meningkatkan kemampuan kondisi fisik yang dimiliki oleh peserta kegiatan ekstrakurikuler.

\section{Daftar Rujukan}

Amiq, F. (2016). Sepak Bola. Malang: Universitas Negeri Malang.

Bella, Y. S. (2015). Survei Kondisi Fisik Dan Keterampilan Teknik Dasar Bola Voli Pada Anak Usia Dini (9-11) Tahun Di Klub Bola Voli Putri Wahana Utama Purwodadi Tahun 2013. Journal Of Physical Education, Sport, Health and Recreations, 4(5), 1799-1806.

Budiwanto. (2012). Metodologi Latihan Olahraga. Malang.

Ghazali. (2016). Kontribusi Kekuatan Otot Lengan Terhadap Kemampuan Servis Atas Atlet Bolavoli. 3(1), 1-6.

Gunawan, I. P. A., Dewi, I. K. A., \& Santika, N. A. (2016). Pelatihan Meloncati Rintangan Setinggi 50cm Ke Kiri Ke Kanan 10 Repetisi 3 Set Meningkatkan Daya Ledak Otot Tungkai Siswa Putra Peserta Ekstrakurikuler Bola Voli Smp Neger 2 Mengwi Tahun Pelajaran 2015/2016. Jurnal Pendidikan Kesehatan Rekreasi, 2(2), 52-60.

Hanafi, M., \& Prastyana, B. R. (2019). Metodologi Kepelatihan Olahraga Tahapan \& Penyusunan Program Latihan. Jakad Media Publishing.

Harsono. (2015). Kepelatihan Olahraga. Bandung: Remaja Rosdakarya.

Lestari, R. Y. (2016). Peran Kegiatan Ekstrakurikuler Dalam Mengembangkan Watak Kewarganegaraan Peserta Didik. Untirta Civic Education Journal, 1(2), 136-152. https://doi.org/10.30870/ucej.v1i2.1887

Ma'mun, S., \& Syafei, M. M. (2019). Hubungan Kekuatan Otot Lengan, Koordinasi Mata Tangan, dan Rasa Percaya Diri dengan Keterampilan Smash pada Ekstrakulikuler Permainan Bola Voli di SMPN 3 Tirtajaya Karawang. Jurnal Speed (Sport, Physical Education, Empowerment), 2(2), 39-48.

Maulidin. (2017). Hubungan Power Otot Lengan Dan Kekuatan Genggaman Dengan Hail Service Slice Pada Permainan Tenis Lapangan Pada Mahasiswa Fpok Ikip Mataram. Jurnal Ilmiah Mandala Education, 3(1), 314-325.

Nasution, S. (2015). Hubungan Kekuatan Otot Lengan dan Percaya Diri Dengan Keterampilan Open Spike Pada Pembelajaran Permainan Bola Voli Atlet Pelatkab Bola Voli Putri Kabupaten Karawang. 3(November), 188-199.

Nurkholis. (2012). Kontribusi Kemampuan Daya Ledak Otot Tungkai, Tinggi Badan dan Kekuatan Otot Lengan Terhadap Ketepatan Sasaran Pukulan Open spike Olahraga BolaVoli. Pendidikan Kepelatihan Olahraga, Fakultas Ilmu Keolahragaan, UNESA, 1-5.

Nurrochmah, S. (2015). Efektivitas Pelatihan Beban Dinamis Dan Statis Untuk Meningkatkan Kekuatan daya Ekplosif Otot Tungkai dan Lengan. Jurnal Iptek Olahraga, 17(3).

Purnama, S., Haryadi, I., Hariono, A., Subroto, \& Twisyono. (2017). Modul Penataran Pelatih Olahraga. Jakarta.

Sovensi, E., Supriyadi, M., \& Suhyd, M. (2019). Kondisi Fisik Pemain Bola Voli Klub Di Kota Lubuklinggau. Jurnal Gelanggang Olahraga, 2(2), 13-25.

Sudarsini. (2013). Pendidikan Jasmani dan Olahraga. Malang: Universitas Negeri Malang.

Sumaryoto, \& Nopembri, S. (2017). Pendidikan Jasmani, Olahraga dan Kesehatan SMA/MA/SMK/MAK Kelas IX. JAKARTA: Pusat Kurikulum dan Perbukuan, Balitbang, Kemendikbud.

Sya'bani, C. R., \& Nurrochmah, S. (2020). Pengaruh latihan kelincahan s-run dan z-run terhadap peningkatan kemampuan kelincahan peserta putra ekstrakurikuler bolabasket. Gelanggang Pendidikan Jasmani Indonesia, 3(2), 106-110. 
Sport Science and Health, 3(7), 2021, 467-478

Yodi, R., \& Mardela, R. (2019). Daya Ledak Otot Tungkai dan Otot Lengan Berhubungan Terhapat Kemampuan Smash Bolavoli. 1101-1113. 